discovered in the area. I may, however, recall attention to the Merton Boulder, which lies on the estate of Lord Walsingham, at Merton, in Norfolk. This boulder is regarded by Mr. Whitaker as Neocomian Sandstone, and it measures $12 \times 5$ feet, but being partly under water its thickness could not be ascertained. (See F. J. Bennett, "Geology of Attleborough, Watton, and Wymondham," Geol. Survey Memoir, p. 10.) A more particular account of the Spilsby Sandstone has been given by Mr. A. Strahan, who refers to its tendency to weather into a loose sand in which great blocks of the unweathered rock remain here and there. Hence during the Glacial Period a number of ready-made boulders could have been obtained from the formation. Such blocks have, indeed, been recorded from the Drift in various parts of Suffolk, and some of them have yielded Brachiopoda regarded as Neocomian by W. Keeping and Davidson. (See Strahan, in "Geology of the Country around Lincoln," p. 88.)

H. B. WOODWARD.

\title{
THE LLANBERIS UNCONFORMTTY.
}

Sir,-The courteous letter, which you publish from Professor Bonney in your June number, calls for only two remarks. (1) I am not aware that Professor Bonney has in any case tried to find out for himself whether any stratigraphical statement of mine is fact or fancy. (2) To have once silenced a gun is not to take the fort. How many of the ship's guns are still in action?

J. F, BLAKE.

\section{OBITUARY. \\ MELVILLE ATTWOOD, F.G.S. \\ Born July 31, $1812 . \quad$ Dikd April 23, 1898.}

Melville Atrwood was born at Preseott Hall, Old Swinford, Worcestershire, on July 31, 1812, and educated at Mathew Gibson's Academy, Tranmere, Cheshire, and afterwards studied at the Chemical Laboratory of Messrs. Watson and Pim, of Liverpool.

When quite a young man he was sent out to the Gold and Diamond Mines in Brazil, where he remained some years; on his return to England he leased and worked the celebrated old Ecton Copper Mine in Derbyshire, and was engaged in mining and metallurgical works in the North of England and Staffordshire, and in 1843 he gave zinc a commercial value by successfully rolling the first English spelter. On the 15th October, 1839, he married Jane Alice Forbes, the sister of the late Professor Edward Forbes and of David Forbes, F.R.S., but in 1852, his wife's health becoming critical, he disposed of his interests and sailed for California, hoping that the change might benefit her; at the same time he accepted the position of manager to the Agua Fria Gold Quartz Company (in California), and in 1853 constructed at Grass Valley the first gold-mill in that country, for which he received a vote of thanks and a medal from the State of California. 
$\mathrm{He}$ invented many appliances for the extraction of gold, also scientific instruments, and the "Attwood amalgamator" has been in general use in California and elsewhere for more than forty years.

In 1859 he made the first assays and analyses of the ores from the celebrated Comstock Gold and Silver Vein; and it was through him that the great riches of the above vein were made known to the world.

For the last twenty-five years nearly all his spare moments were given to microscopic work; he prepared his own specimens, and he leaves behind him a most valuable collection of minerals and microscopic slides. He was an intimate and esteemed friend of the late Sir Warington Smyth, Dr. John Percy, John Arthur Phillips, F.R.S., and other well-known scientific men.

$\mathrm{He}$ was able to practise his profession of consulting mining engineer until within a few weeks of his death, which took place at Berkeley, near San Francisco, California, on April 23, 1898, in his eighty-sixth year. His practical experience in gold-mining extended for a period of seventy years, as he was in the Brazilian gold-mines before he reached the age of seventeen.

He was a Fellow of the Geologioal Society, a Member of the Academy of Sciences (California), California State Geological Society, and the San Francisco Microscopical Society. The members of the last-mentioned Society attended in a body the funeral on April 26, with numerous old-time friends.

His contributions to the California Mining Bureau and scientific papers and magazines were numerous. The following is a list of some of his principal writings :-

"On the Milling of Auriferons Vein Stones," August 1, 1878: California State Geological Society.

"Mineralization of Gold," August 20, 1878: California State Geological Society.

“On an Improved Form of Batéa," August 20, 1873: California State Geological Society.

"Wall Rocks of the Bodie Auriferous Lodes," March 4, 1879: California State Geological Society.

"Rough Notes on the Geology of Bodie, illustrating the two ages of Gold," June 13, 1881 : San Francisco Microscopical Society.

"On the Milling of Gold Quartz," Angust 20, 1881: California State Geological Society.

"On the Milling of Gold Quartz," sequel to above paper, 1882 : California State Mining Bureau.

"A simple Working Test for determining the quantity of Gold mechanically combined with Auriferous Vein Matter": California State Mining Bureau.

"Gongo Soco Mine," 1896: San Francisco Microscopical Society.

"Macroscopical Examination," February 14, 1897 : San Francisco Call.

"Mineralogy," 1897 : Sin Francisco Microscopical Society.

GEORGE ATTWOOD. 